\title{
Danuta Łazarska
}

(iD) https://orcid.org/0000-0003-0930-0969

\section{"I remember when at school..." On the importance of autobiographical elements not only for their authors - the students of Polish studies'}

The term "autobiography" derived from Greek means a record of one's own life. Dictionaries define it as works and records which present the life of an author, their fortunes and deeds, events which they witnessed, and their experiences, the evolution of their views and attitudes towards people and the world. ${ }^{2}$ Autobiographies, just like journals, diaries, and letters, are referred to in Polish as personal document literature. ${ }^{3}$ It was defined in a similar vein by Edward Kasperski, who claimed that it is a type of an "expression which within the limits of a specified system of forms specialises in reporting facts and events from the life of its author." According to Philippe Lejeune, a person developing an autobiography, i.e. a prose retrospective story, emphasises their individual fate and personality. ${ }^{5}$

An autobiography "considered as a literary genre, as well as perceived more broadly as a manner of viewing and describing the world consisting of putting

* Ph.D. hab., Professor the Pedagogical University. Pedagogical University, Faculty of Philology, Institute of Polish Philology, Chair of Teaching Literature and the Polish Language, ul. Podchorążych 2, 30-084 Krakow, danutal@op.pl

1 In the text I present the results of my research (financed by myself, i.e. the author of this article).

2 Słownik terminów literackich, J. Sławiński, Ossolineum, Wrocław 1988, p. 47.

3 R. Zimand, Diarysta Stefan Ż., Ossolineum, Wrocław 1990, pp. 6-45.

4 E. Kasperski, "Autobiografia. Sytuacja i wyznaczniki formy", in: Autobiografizm - przemiany, formy, znaczenia, H. Gosk, A. Zieniewicz (eds.), Dom Wydawniczy ELIPSA, Warsaw 2001, p. 10. [Unless indicated otherwise, English versions of quotations were translated from Polish]

5 Ph. Lejeune, Wariacje na temat pewnego paktu. O autobiografii, R. Lubas-Bartoszyńska (ed.), trans. A. Labuda et al., Universitas, Krakow 2001, p. 1. 
it through a filter of sensations and experiences of its author"6 fits the category of autobiographism. However, it is not always the case that "every autobiographical account takes the shape of an autobiography." An autobiographical expression entails the construction of a relationship between the sender and the recipient, supported by trust in the veracity of the details included in the work. According to Małgorzata Czermińska, the important elements of such literature include the place and the existence of an autobiographical attitude of the author who creates it. ${ }^{8}$ One could also claim that the record of one's life becomes a reflection of the societal changes which to a lesser or greater extent impact the person editing the autobiography. It also reflects the personal identity of the sender. "Here, according to Regina Lubas-Bartoszyńska, the most important question for one's identity, i.e. 'who am I?' or 'how am I?' are the basic questions."'

A major role in any broad or narrow attempts at presenting one's own life is played by autobiographical memory, i.e. the memory of one's individual past. By considering it as permanent declarative memory, psychologists have defined its components: episodic and semantic. ${ }^{10}$ Autobiographical memory enables the person to store in their mind facts regarding consecutive stages of life and related memories. Therefore, both episodic and semantic memories, strongly conditioned by emotional experiences, may apply to many matters, e.g. family or school affairs, or the period of university studies. Thus, the memory of the history of one's own life remains strictly related to the autobiographical knowledge of the person reminiscing on their past and with the process of creating autobiographical records. It also influences the shaping of the identity of an individual who lived in a specific place and at a specific time, and who was subject to various influences of the surrounding reality. Quoting Anthony Giddens, a sociologist, one would have to consider that the identity

It is «the self as reflexively understood by the person in terms of her or his biography». Identity here still presumes continuity across time and space: but self-identity is

6 A. Wnuk, "Powieść poetycka wobec autobiografii", Świat Tekstów. Rocznik Słupski 2011, issue 9, p. 15.

7 E. Kasperski, op. cit.

8 M. Czermińska, Autobiografia i powieść, czyli pisarz i jego postacie, Wydawnictwo Morskie, Gdańsk 1987, p. 12.

9 R.Lubas-Bartoszyńska, "Tożsamośćiautobiografia”, Przestrzenieteorii 2, Poznań 2003, p. 143. https:// repozytorium.amu.edu.pl/bitstream/10593/9218/1/009_Regina_Lubas_Bartoszy\%C5\%84ska_ To\%C5\%BCsamo\%C5\%9B\%C4\%87_i_autobiografia_139_157.pdf [accessed on 7.07 2017].

10 A. Walczak, B. Wiśniewska, "Pamięć autobiograficzna", Psychiatria i Psychologia Kliniczna 2011, issue 11 (1), p. 52; http://www.gazeta.psychiatria.com.pl/index.php/wydawnictwa/2011-vol-11no-1/pamiec-autobiograficzna?aid=32 [accessed on: 16.05.2016]. 
such continuity as interpreted reflexively by the agent. This includes the cognitive component of personhood. ${ }^{11}$

Specialists in the field analyse autobiographical works from various angles. These include focusing on the attitudes of the authors of recollections on their own lives, the manner in which they establish contact with readers, or the impact of autobiographical memory on the construction of such records. They also seek the relationships between works of different genres and autobiographies, and in defining the importance of the latter in the life of their authors and readers. ${ }^{12}$ What other role can an autobiography fulfil? It can also serve the purpose of diagnosing various problems, which stem from social, moral and cultural changes, and the search for their solutions.

\section{Research objectives and method}

In the article I present the results of my study of students starting Polish studies. I asked them, just as I did with their older colleagues, to create anonymous and free reflections on the figure of a student, i.e. a student as a human and as a recipient of literature. ${ }^{13}$ In total, I collected 136 works by first year students. Please bear in mind that the collected works are not autobiographies. Nonetheless, they do include more or less extensive autobiographical sections, i.e. the most interesting for me were the traces of the school lives of the study subjects. I diagnosed the problems which existed at school, as indicated by the subjects, the places and attitudes of the authors of these texts, and the roles of the latter. It is also important to study the impact of emotions and the memory of an individual's past, and its function on the development of school memories, and on the development of various habits of thinking about oneself, pupils, teachers, and literature. All that leads to the formulation of conclusions on the importance of these profiled autobiographical elements for their authors and for the recipients of such writings, as well as Polish philological teaching for schools and universities. Therefore, I consider the study

11 A. Giddens, Nowoczesność i tożsamość. „Ja” i społeczeństwo w epoce późnej nowoczesności, trans. A. Szulżycka, Wydawnictwo Naukowe PAN, $1^{\text {st }}$ edition reprinted, Warsaw 2002, p. 75. [English version: A. Giddens, Modernity and Self-Identity. Self and Society in the Late Modern Age, Polity Press, Oxford 1991, p. 53]

12 Cf. A. Wnuk, op. cit., pp. 22-23.

13 I offered a detailed discussion of the study groups in my book: Osoba ucznia w świadomości studentów polonistyki. O związku literaturoznawstwa z dydaktyką, Wydawnictwo Naukowe UP, Krakow 2015, pp. 94-114. In this article, I focussed solely on the autobiographical elements present in the texts by first year students. The matters related to the autobiographical elements, as identified in the studied texts, were not published, though they were strictly related to the research results and conclusions discussed in the indicated publication. 
of texts in which students presented events from their school youth as important and new in relation to various discussions by specialists on the topics of pupils and school, and the impact of school on the pupils' later fortunes.

I utilized document analysis to conduct the study. It consists of a description and interpretation of various broadly considered works. According to educators the interpretations

are created either through the intentions of their creators, or as a result of special guidelines of a person who initiates and conducts a study. Such documents usually constitute a more or less finished product of specific activities of children, the youth or adults. Therefore, sometimes it is not the course of the activities which result in the creation of a work that is the main object of the analysis of documents, but the product itself as the final result of the performed activities. ${ }^{14}$

Document analysis is used for a qualitative study. Its goal is not only to examine the internal world of the author of a text, but to focus on the external world which surrounds them. From the sociological point of view, it enables the analysis and interpretation of various social phenomena related to the experiences of an individual, and their relations and interactions with others. ${ }^{15}$

\section{Testimonials, experiences and... provocation}

It is worth while to begin the consideration of the issue by giving voice to the authors of the studied texts. Here are several examples: ${ }^{16}$

(...) w szkołach nikt się nie zastanawiał nad uczniem - człowiekiem, który ma lepszy lub gorszy dzień, coś się z nim w środku dzieje i dzieje się coś w jego rodzinie. Nie przypominam sobie lekcji, na których polonistka i inni nauczyciele próbowali we mnie dostrzec normalnego człowieka z emocjami. Ale dobrze pamiętam, że ciągle mówili, co i jak trzeba robić, ile przeczytać, jak się uczyć, żeby zdać maturę. $[(.$.$) at school no one cared about a pupil - a person who had better and worse$ days, what was happening inside them, or what was happening in their family. I cannot remember a lesson during which a Polish teacher or other teachers would try to see in me a regular person with emotions. But I remember well

14 M. Łobocki, Metody i techniki badań pedagogicznych, Oficyna Wydawnicza IMPULS, Krakow 200o, p. 212.

15 U. Flick, Jakość w badaniach jakościowych, trans. P. Tomanek, Wydawnictwo Naukowe PWN, Warsaw 2011, pp. 13-14.

16 I should explain that the quoted fragments of texts by first year students were not corrected in any way. 
enough them telling us what should be done and how, how much to read, how to study to pass the matura exam]

Szkolny stres wpłynął źle na moje relacje z rodzeństwem, mamą i chęć do życia. Jak sobie o tym przypomnę to wydaje mi się, że zabraknie mi w życiu czasu i siły na spokojne i zwykłe życie. Czułem się w szkole jak człowiek, ale jakiś chory - bo zestresowany i bardzo taki jakiś malutki przy nauczycielach i zdolniejszych uczniach. [School stress negatively impacted my relations with my siblings, mum, and my will to live. Now when it comes back to me it seems that I won't have enough time or strength in my life to lead a peaceful regular life. At school I felt like a person, but as if a sick one-because I was stressed and somewhat small when facing the teachers and more talented pupils.]

Uczniowie to nie roboty! Chociaż goni się ich do roboty, a mało zachęca lub wcale nie zachęca. Taki przymus pamiętam z mojej szkoły. Zawsze przeciw temu się buntowałam i odczuwałam nienawiść do lekcji, do nauczyciela. Nie mam nic przeciwko, żeby się uczyć, ale wolałabym, żeby mnie w ciekawy sposób motywować do czytania utworów. Pozytywnie było w szkole podstawowej (bardzo lubiłam ciepłą, życzliwą polonistkę, a ona mnie i wszystkich z mojej klasy), źle, gdy byłam w gimnazjum i liceum. Bo tam był pęd i nerwy, że znowu czegoś nie przeczytałam i nie wiem, a trzeba było, bo będzie źle na egzaminach. Zaraz się denerwuję, gdy o tym sobie przypominam. Został mi uraz do czytania książek.

[Pupils are no robots! And yet they are made to work hard, yet with little or no incentive. I remember that pressure from my school. I always rebelled against that and I felt hatred towards lessons, to the teachers. I see no problem in learning, but I would prefer it if I had been motivated in an interesting way to read works. It was positive at primary school (I liked my warm kind Polish teacher very much, and she liked me and everyone in my class). It was bad at middle school and high school. There you had the constant race, and anxiety that once again I didn't read something and that I didn't know but I should have had because otherwise the exams would turn out poorly. I become anxious even reminiscing that. I have this trauma about reading books.]

(...) uczeń jest człowiekiem, wiem to dobrze, bo chociaż dopiero co przyszedłem na studia i jestem studentem - człowiekiem. Pamiętam, żew szkole podstawowej czułem się jak człowiek na każdej lekcji, ale najbardziej na polskim. Gimnazjum przeleciało tak szybko, że nie pamiętam, żadnych odczuć szkolnych wskazujących, że byłem za człowieka uważany. A byłem nim, bo czułem smutek i żal, gdy zmarł kolega z klasy i stres na każdym teście i myślałem (wiadomo: myślę, więc jestem) o uczuciach o nawiązaniu poważnej znajomości z moją koleżanką spoza szkoły. Wspominając to, jak było w liceum, uważam, że nauczyciele chyba nie mieli i nie mają czasu na myślenie o uczniu-człowieku lub nie widzą takiej potrzeby. 
$[(. .$.$) a pupil is a person; I know that well because though I just started studying and$ I am a student - a person. I remember that at primary school I felt like a person in every class, but most of all during Polish classes. Middle school went past so quickly that I don't remember, no school experiences indicating that I was considered a person. But I was a person because I felt sadness and grief when my classmate died, and stress during every test, and I thought (clearly: I think, therefore I am) about pupils about establishing a serious acquaintance with a friend of mine from outside the school. When reminiscing on high school I think that the teachers probably didn't have time for thinking about the person-pupil, or they didn't find it necessary.]

W liceum [...] stawałam się rzeczą w rękach nauczycieli ciągle krytykujących mnie i resztę, a czasami byłam człowiekiem, z którym próbowano rozmawiać tak o życiu, ale częściej poza lekcjami, a nie wtedy gdy przerabialiśmy jakieś utwory. Moim zdaniem zależało to od stosunku nauczyciela do pracy, do klasy i konkretnego ucznia. Przy nauczycielu lubiącym uczniów czułam się jak człowiek, przy innym jak kukła pociągana za sznurki na lekcji i jeszcze na dodatek w domu również byłam kukłą. Pamiętam, że w szkole wcześniej było różnie, ale najbardziej ludzko czułam się w szkole podstawowej na polskim, na którym robiliśmy z naszą panią różne rzeczy (np. teatralne). Morał z tego taki, że to, czy zobaczę w uczniach ludzi będzie zależeć ode mnie - nauczycielki i moich doświadczeń.

[At high school [...] I became an object in the hands of the teachers who constantly criticised me and the rest, while sometimes I was a person with whom they tried to talk about life, but more often outside the classroom, not when we were analysing some texts. As I see it, it all depended on the attitude of a specific teacher to their work, class and a specific pupil. In the company of a teacher who liked pupils I felt like a person, while in the company of another I felt like a puppet whose strings were pulled during a class, and, additionally, I was a puppet at home, too. I remember that early at school it was so-so, but I felt like a person the most at primary school during Polish classes, when we did various things with our teacher (e.g. staged plays). The moral of the story is that it depends on me-the teacher and my experiences whether I will see a person in a pupil or not.]

(...) nawet, jeśli byłoby inaczej, uczniowie w szkole są przede wszystkim uczniami. Zdecydowanie tak uważam, obserwując aktualne życie szkolne. Szkoła zawsze była dla mnie szkołą, a ja w niej uczennicą, która na lekcjach odbierała literaturę i była również człowiekiem. W każdej szkole i na każdej lekcji zawsze czułam się człowiekiem i tak mnie traktowano.

$[(. .$.$) even if it would be different, pupils at school are most of all pupils. I strongly$ think so as I observe the current school life. School has always been school for me, and I was there a pupil who in classes received literature and was also a person. At every school and in every class, I always felt like a person and I was treated that way.] 
What connects the above-quoted fragments selected from many other similar ones? They are bound together through these subjects' negative and positive thoughts about their not so distant school past. A major issue for the subjects was how a pupil was perceived at school. Usually as someone who feels at school like an object, not as a person who experiences various emotions and events in their private and school life. Such subjective observations by students who have just stopped being pupils could be considered outrageous. There is no shortage of teachers who make sure pupils are treated as individuals and placed in the centre of the planned and conducted classes. However, it is best to consider the texts by the students as a diagnosis of problems present at schools influenced by the various changes of the $21^{\text {st }}$ century. What were the problems indicated by the study subjects?

One such problem was the incorrect understanding among educators of what it means to accept the individual nature of pupils when designing and conducting classes, and how to understand the formative role of education and its philosophy, as also indicated by Krzysztof Koc. ${ }^{77}$ Another issue was that sometimes those responsible for the education and upbringing of young adults succumb to the pressure of time. That anxiety in teachers about not fulfilling the study material results in their adjusting pupils to Polish as a class subject and not to the capabilities, needs, and interests of pupils, as it has been indicated by educators for many years. ${ }^{18}$ Such a situation prevents teachers from considering a pupil a person. That, in turn, does not help create objectives of Polish education which places teenagers at the foundation. Neither does it help to prepare them for independent analysis and interpretation of various cultural texts and seeking a place for themselves in later life.

Another problem indicated by the study subjects were the methods used to motivate pupils to prepare for and engage in various activities during classes. Students mainly associated this problem with teachers' lack of time. There were also the infrequent statements about teachers lack of creativity in triggering teenagers to work. Much has already been written in the subject literature on the role of teachers in inspiring pupils to work during Polish classes. One has to agree with those like Barbara Myrdzik or the authors of the texts included in the book Twórcze praktyki polonistyczne, who expect Polish teachers to develop pupil creativity and imagination, and who suggest how to motivate children and youth to read literature, and actively and responsibly participate in culture. ${ }^{19}$

17 K. Koc, "Filozofia nauczania", in: Innowacje i metody. W kręgu teorii i praktyki, M. Kwiatkowska-Ratajczak (ed.), Wydawnictwo Naukowe UAM, Poznań 2011, p. 68.

18 e.g. Jan Polakowski, Zenon Uryga, Barbara Myrdzik, and Maria Jędrychowska.

19 Cf. B. Myrdzik, Zrozumieć siebie i świat. Szkice i studia o edukacji polonistycznej, Wydawnictwo UMCS, Lublin 2006, pp. 230-266; Twórcze praktyki polonistyczne, A. Janus-Sitarz (ed.), Universitas, Krakow 2015. 
Another problem indicated in the students' texts on school life were the relations between pupils and Polish teachers. First year students saw these poor relations as the reason for the dissatisfaction of teachers in their work, and their already established negative attitudes towards specific classes and students. Students also reported on the arrogant attitudes among pupils towards school and teachers, and on the lack of authority figures among the latter. The analysis of the texts indicated that the study subjects felt more like objects than subjects during classes; it also indicated incorrect interpersonal relations, distorted dialogue between school entities, which is "increasingly problematic, according to Maciej Wróblewski, or even undesired," ${ }^{20}$ and low motivation among pupils to fulfil tasks which may, e.g.: (1) cause the development of aggressive attitudes of teenagers towards other people, (2) impact family relations where young people do not always feel they are treated as people, (3) cause unwillingness to participate in classes, often in combination with school phobias, (4) shatter the system of values, and (5) cause a lack of desire to read or a low willingness to experience literature. If one considers the fifth factor, which impacts the shaping of teenagers' attitudes towards works of literature, one should agree with a statement by Anna Janus-Sitarz:

The attitude of young people to reading, the ability to find in books that which impacts them, the ability to hear from the pages of books the questions posed by literature, all that is strongly influenced by their individual approaches to reading and the model of encounters with literature as proposed to pupils by their Polish teachers, but also, more generally, the style of a teacher's teaching. ${ }^{21}$

In the light of the above discussion, one should also consider the place of the authors in the students' autobiographical fragments. They, being first year students, strongly associated with, as they put it, "school brothers and sisters", "the schooler community", or "pupil soul mates". Their strong attachment to their lives as pupils should not come as a surprise, as they fulfilled for twelve years one of the social roles with which they were assigned. The analysis of the more or less extensive autobiographical elements present in all of the collected texts indicated that when writing them students assumed one of the two attitudes: (1) introvert, where the illustration of the internal experiences of the writing $I$ were a person's internal emotions, and (2) extrovert, where the external reality was viewed from the perspective of the speaking $I$. The identified attitudes distributed throughout the texts referred to those which the researchers of autobiographical texts assign to authors of the stories of one's own lives.

20 M. Wróblewski, Człowiek w przestrzeniach szkoły. Studium antropologiczne, Wydawnictwo UMK, Toruń 2014, p. 241.

21 A. Janus-Sitarz, W poszukiwaniu czytelnika. Diagnozy. Inspiracje. Rekomendacje, Universitas, Krakow 2016, p. 91. 
Therefore, a question arises about the students' intentions in recalling their school years. In the light of the collected texts, three purposes for creating such records emerged. ${ }^{22}$

The first purpose: to offer testimony - for $88.97 \%$ of the authors of the works it meant revealing what it was like at school and what happened in particular during Polish lessons. The development of their reflections on being a pupil became for the first-year students a pretext to inform from a witness perspective on the reality they knew well, and on the people with whom they came into contact. It also proved important for them to discuss events which happened mainly during literature lessons, which they participated in as witnesses or which they observed. Those applied to, e.g. the modes of motivating pupils to study, read, and to discuss works of literature, and the attitude of the youth to literature, Polish teachers, and school in general. They also used that urge, which could be referred to as autobiographical, to present their place within that relationship, and to relate their own lives to their school existence.

The second purpose: confessing about one's own experiences - entailed, as stated by $60.29 \%$ of the students, e.g. a (dis)like for reading literature, teachers, and school in general. It also proved important for the students (former pupils) to use their personal experiences in recording their negative and positive emotions, which were strongly related to, e.g. their family homes, first love, and the impact of such experiences on them as persons. It was clear that the fact of confessing their internal experiences and the mainly negative emotions still deeply rooted in the study subjects impacted their texts. This was also connected with expressing themselves as persons usually manifesting their objection to the school environmet, which surrounds pupils/students. However, I should stress that the texts I collected also included statements in which the study subjects presented positive approaches to school, teachers, literature, and life.

The third purpose: provoking the reader - that applied to the attempts by $39.7 \%$ of the authors to establish a connection with the readers of the students' school autobiographies, and provoke the readers to think about students' past and the situation of current pupils, strongly inscribed in the various spaces of the contemporary world. Though such fragments lacked any direct address to the reader, the manner in which they were written and the many questions and exclamations they included encouraged a potential reader to develop deep considerations for the issues raised by the authors of the personal school recollections, and to react to these issues. They may also spur in a reader the need to: (1) portray the students, both as pupils and later as first year university students, (2) diagnose the modes of thinking about teachers, pupils and literary texts which they developed at school,

22 The total of the data exceeds one hundred per cent as in the collected works I diagnosed more than one purpose for developing such texts. 
(3) examine their linguistic skills of building such expressions, and (4) consider the manner in which the study subjects were prepared for fulfilling the profession of a Polish teacher.

The above-discussed intertwined purposes of the autobiographical fragments written by the student subjects bring to mind the discussions by Czermińska. ${ }^{23}$ She referred to the narrations of authors in autobiographical writings as: testimony, confession and a challenge posed for readers. They also indicated the budding need inside people who are starting Polish studies to write about themselves, and to write and create themselves.

Therefore, the autobiographical elements identified in the analysed texts enabled the students to fulfil additional markers of the autobiographical attitude. And it entails also the personal participation of a writer in the expression, and their responsibility for the words being written, and the internal need to communicate themselves to a specific You. ${ }^{24}$

When introducing autobiographical fragments into their musings on pupils as people and recipients of literature, the study subjects sometimes referred rather emotionally to the experiences from their own school life. Thus, they indicated the subjective manner of experiencing that which they experienced at school. The intensity of emotions, from apathy to agitation and fear, impacted their deeply rooted ways of thinking about themselves as people and pupils, about other pupils, and about teachers. Therefore, one could state that their classroom emotions, still vivid for them, framed their texts and strongly impacted the ways in which the subjects organised the recollections of their school lives. In fact, emotions play a major role: "they are treated by the body as an indicator of the importance of pieces of information - those which a person is to code and those which a person is to reproduce." ${ }^{25}$ That means that they have a major impact on the formation of recollections and on the development of all ways of thinking about school.

Autobiographical memory had an influence on the students' development of the autobiographical fragments and positive and/or negative emotional stimulation. According to specialists it

23 M. Czermińska, Autobiograficzny trójkąt: świadectwo, wyznanie i wyzwanie, Universitas, Kraków 2000, pp. 19-25.

24 Ibid., p. 17.

25 A. Fijałkowska, W. Gruszczyński, "Organizacja wspomnień emocjonalnych w pamięci autobiograficznej”, Psychiatria Polska 2009, vol. XLIII, issue 3, p. 341, http://www.psychiatriapolska. pl/uploads/images/PP_3_2009/Fijalkowska\%20s341_Psychiatria\%20Polska\%203_2009.pdf [accessed on: 16.05.2016]. 
Fulfils vital functions enabling an individual to properly function, gather knowledge about themselves, and it enables them to establish and maintain interpersonal relations. $^{26}$

Specialists in the field offer various classifications of the functions of the memory of an individual's past. Therefore, one could talk about intrapersonal and interpersonal functions ${ }^{27}$ However, it is worthwhile to consider the functions of autobiographical memory in a bit broader perspective. Tomasz Maruszewski identified five of those, i.e.: the informative, communicative, interpersonal, motivation-emotional, and organisational functions. ${ }^{28}$ The results of the study of first year students proved the active influence, though to varying degrees, of the specified functions of autobiographical memory, which contained descriptions of the school lives of the authors of the recollections. In the light of the analysis of the texts, the purposes of individual functions are as follows:

- The informative function enabled the students to extract details on their behaviour (1) as pupils during Polish lessons and the activities undertaken in contact with teachers and works of literature which were favourable for them at that time, and (2) as students-people and recipients of literature;

- The communicative function helped the subject think about the ways of establishing contacts with school Polish teachers and the literature they read, as they reminisced about themselves and their situations and positions during these lessons and various related experiences;

- The interpersonal function became the basis for formulating reflections on the necessity to build and the importance of maintaining bonds between pupils and teachers (one could also assume that between students as well);

- The motivation-emotional function helped them realise their (un)willingness to become teachers and the reasons for following/rejecting that career path in the future, and the manner of treating pupils during lessons;

- The organisational function helped the students in recording sometimes short observations, postulates (sometimes in the form of enumerations), and in selecting school recollections: those positive ones, which, according to them, they presented selectively due to a lack of time, and the negative ones, which were presented also in a fragmentary manner due to the subjects' unwillingness to harm teachers or their schools.

The functions of autobiographical memory identified, based on student recollections, proved the strong influence of past events on the attitudes of adult perso-

26 A. Walczak, B. Wiśniewska, op. cit., p. 53.

27 Ibid., p. 52.

28 T. Maruszewski, Pamięć autobiograficzna, Gdańskie Wydawnictwo Psychologiczne, Gdańsk 2006. 
nas to themselves, teachers, literature, and life. On that basis one could also diagnose the attitudes of the subjects towards the reality in which they had to function, and the impact of social, moral, and cultural changes on them, as people and prospective teachers.

\section{Conclusions}

The above discussion leads to the following question: how important were the autobiographical elements for the students, i.e. their authors? Based on the analysed material, it would seem extremely important. For some these elements offered a form of catharsis, cleansing them of negative school emotions. For others they became an opportunity to test themselves, their credibility, the maturity of their thinking about themselves (also as recipients of others and of literature), their teachers, and the lessons they conducted. For still others they offered a chance to: display their sensitivity, that what they considered the most important in life, and their own identities as persons who for a dozen or so years fulfilled the social function of pupils. Therefore, they also constituted an encouragement to peer into oneself as a possible prospective Polish teacher.

The autobiographical elements studied in the students' texts, different for various reasons from those which can be found in personal document literature, offer extraordinary cognitive value for school and university Polish education. Its task is to react to the negative outcomes of the changes of the $21^{\text {st }}$ century, and to aid young people in finding their way in the modern world. That is another conclusion of the study. The personal experiences of former pupils, focussed around their school lives and their strongly related private lives, were living proof of the personal experiences of each of the study subjects. Subjects who were faced with the choice of selecting the teaching specialisation but who remembered themselves as pupils. Persons who in developing their texts based on their school recollections indicated the problems which schools and universities face nowadays.

The basic task of school Polish philology teaching is to ensure a personalisation of education and upbringing objectives which, as never before, will:

1) prevent the anthropological and ethical lostness of pupils,

2) support the development in pupils of the skills of coping with the chaos of thoughts about people, and their attitudes towards others,

3) help make pupils care about other people, and shape their systems of values,

4) help to develop pupils' ability to independently analyse and interpret the various (positive and negative) phenomena of modern times,

5) oppose all schematic conduct in teacher activities which might objectify teenagers,

6) oppose the insufficiency of time for considering pupils as people. 
Then, the task of university Polish philological education is to prepare future educational staff in a way which will help develop their ability to notice pupils as people. It is no easy task to achieve that objective, though it has been postulated by educators for many years. That is because it requires not only firm interdisciplinary knowledge and many skills, but also a change in how students think about pupils and teachers, and the development in prospective teachers the will to notice, or to keep noticing, people in others. That entails, first the identification of their individual characteristics, talents, various weaknesses, and the positive and negative impact of teenagers on the reality in which they function, and then designing common lessons, which match the collected results of conducted diagnoses.

The above-discussed process of Polish philological education is not supported by the contemporary world which surrounds young people (pupils and their future teachers). It is declaratively opened to people as subjects and to all activities for people's benefit, but in reality, it is full of activities which serve the objectification of people. These cause the loosening of interpersonal bonds. It also results in an axiological disruption and the development of aggression. Stanisław Bortnowski aptly noted that pupils

live in a never-ending race but they do not really know "where" they are running to. An unstable world has shown them huge opportunities, yet it also gave them extremely thin chances of fulfilling their exaggerated dreams. Therefore, it is a generation which is unstable and unpredictable, with an underlying passivity. ${ }^{29}$

The quoted thought by the educator should also be applied to students and Polish philology teachers as they are also largely impacted by the world in which they live, and the social-cultural changes occurring in it.

In conclusion, one should consider that the various modes of diagnosing students beginning their studies become useful for many reasons. They may shed light on:

- the influence exerted by teachers on pupils and their adult (private and student) lives with whom they come into contact at various stages of their school education,

- the directions of the thinking of people who start studies about other people, interpersonal relations, and the process of school education,

- the ability of prospective teachers to find their place in the contemporary reality or the lack of such abilities or needs.

An important aim of such studies is to consider the concept of school and university education and in those the place and the roles of pupils/students and teachers. There is a point in identifying the problems of schools and Polish education from the

29 S. Bortnowski, "Nasz uczeń jako Inny", in: Edukacja polonistyczna wobec Innego, A. Janus-Sitarz (ed.), Universitas, Krakow 2014, p. 193. 
point of view of its participants if it supports a debate on the ways for improving the diagnosed situation. One such way is to develop pupil and student sensitivity to a person's subjectivity. Literature becomes vital in opening teenagers and their future teachers to thinking about other people and building the appropriate relations between the I and the You. It is literature that guides the "policy of sensitivity"30 at every level of Polish education. By opening readers to their personal experiences, literary texts show them and help them realise who a person is, and who a reader becomes in contact with literature. According to Myrdzik works of literature can (particularly through literary characters) stimulate the intellect and emotions of readers, leaving inside them a lasting impression and triggering an urge to undertake various actions. ${ }^{31}$ Therefore, one should follow the path of literature "keeping to, as Ryszard Nycz posited, its, routed by the language, path through experiencing oneself and the world. Let us finally use literature as a guide, not just an object of our study." 32

\section{Bibliography}

Bortnowski Stanisław, "Nasz uczeń jako Inny”, in: Edukacja polonistyczna wobec Innego, Anna Janus-Sitarz (ed.), Universitas, Krakow 2014.

Czermińska Małgorzata, Autobiografia i powieść, czyli pisarz i jego postacie, Wydawnictwo Morskie, Gdańsk 1987.

Czermińska Małgorzata, Autobiograficzny trójkąt: świadectwo, wyznanie i wyzwanie, Universitas, Krakow 2000.

Fijałkowska Aleksandra, Gruszczyński Wojciech, "Organizacja wspomnień emocjonalnych w pamięci autobiograficznej”, Psychiatria Polska 2009, vol. XLIII, issue 3, p. 341, http://www.psychiatriapolska.pl/uploads/images/PP_3_2009/Fijalkowska\%20s341_Psychiatria\%20Polska\%203_2009.pdf [accessed on: 16.05.2016].

Flick Uwe, Jakość w badaniach jakościowych, trans. Paweł Tomanek, Wydawnictwo Naukowe PWN, Warsaw 2011.

Giddens Anthony, Nowoczesność i tożsamość. „Ja” i społeczeństwo w epoce późnej nowoczesności, trans. Alina Szulżycka, Wydawnictwo Naukowe PAN, $1^{\text {st }}$ edition reprinted, Warsaw 2002.

30 M.P. Markowski, Polityka wrażliwości. Wprowadzenie do humanistyki, Universitas, Krakow 2013, p. 122.

31 B. Myrdzik, "Wpływ doświadczenia na proces lektury czytelnika. Refleksje dydaktyczne", in: Doświadczenie lektury. Między krytyką literackąa dydaktyką literatury, K. Biedrzycki, A. Janus-Sitarz (eds.), Universitas, Krakow 2012, p. 140.

32 R. Nycz, Poetyka doświadczenia. Teorie - nowoczesność - literatura, Universitas, Warsaw 2012, p. 419. 
Janus-Sitarz Anna, W poszukiwaniu czytelnika. Diagnozy. Inspiracje. Rekomendacje, Universitas, Krakow 2016.

Kasperski Edward, “Autobiografia. Sytuacja i wyznaczniki formy”, in: Autobiografizm - przemiany, formy, znaczenia, Hanna Gosk, Andrzej Zieniewicz (eds.), Dom Wydawniczy ELIPSA, Warsaw 2001.

Koc Krzysztof, "Filozofia nauczania”, in: Innowacje i metody. W kregu teorii i praktyki, Kwiatkowska-Ratajczak Maria, Wydawnictwo UAM, Poznań 2011, pp. 47-73. Lejeune Philippe, Wariacje na temat pewnego paktu. O autobiografi, Regina Lubas-Bartoszyńska, Universitas, trans. Aleksander Labuda et al., Krakow 2001.

Lubas-Bartoszyńska Regina, “Tożsamość i autobiografia”, Przestrzenie teorii 2, Poznań 2003. https://repozytorium.amu.edu.pl/bitstream/10593/9218/1/009_Regina_Lubas_Bartoszy\%C5\%84ska_To\%C5\%BCsamo\%C5\%9B\%C4\%87_i_autobiografia_139_157.pdf [accessed on: 7.07.2017].

Łobocki Mieczysław, Metody i techniki badań pedagogicznych, Oficyna Wydawnicza IMPULS, Krakow 2000.

Markowski Michał Paweł, Polityka wrażliwości. Wprowadzenie do humanistyki, Universitas, Krakow 2013.

Maruszewski Tomasz, Pamięć autobiograficzna, Gdańskie Wydawnictwo Psychologiczne, Gdańsk 2006.

Myrdzik Barbara, "Wpływ doświadczenia na proces lektury czytelnika. Refleksje dydaktyczne", in: Doświadczenie lektury. Między krytyka literacka a dydaktyką literatury, Krzysztof Biedrzycki, Anna Janus-Sitarz (eds.), Universitas, Krakow 2012, pp. 131-141.

Myrdzik Barbara, Zrozumieć siebie i świat. Szkice i studia o edukacji polonistycznej, Wydawnictwo UMCS, Lublin 2006.

Nycz Ryszard, Poetyka doświadczenia. Teorie - nowoczesność - literatura, Universitas, Warsaw 2012.

Słownik terminów literackich, Janusz Sławiński, Ossolineum, Wrocław 1988.

Twórcze praktyki polonistyczne, Anna Janus-Sitarz (ed.), Universitas, Krakow 2015.

Walczak Aleksandra, Wiśniewska Barbara, "Pamięć autobiograficzna”, Psychiatria i Psychologia Kliniczna 2011, issue 11 (1), p. 52; http://www.gazeta.psychiatria.com. pl/index.php/wydawnictwa/2011-vol-11-no-1/pamiec-autobiograficzna?aid=32 [accessed on: 16.05.2016].

Wnuk Agnieszka, "Powieść poetycka wobec autobiografii", Świat Tekstów. Rocznik Stupski 2011, issue 9.

Wróblewski Maciej, Człowiek w przestrzeniach szkoły. Studium antropologiczne, Wydawnictwo UMK, Toruń 2014.

Zimand Roman, Diarysta Stefan Ż., Ossolineum, Wrocław 1990. 


\section{„Pamiętam, że w szkole ..... O znaczeniu wątków autobiograficznych nie tylko dla studentów polonistyki - ich autorów}

\section{Streszczenie}

Autorka artykułu wychodzi od rozważań na temat rozumienia terminu „autobiografia" przez znawców tematu i jej roli. Następnie przedstawia wyniki analizy wątków autobiograficznych, obecnych w pisemnych pracach 136 słuchaczy rozpoczynających studia polonistyczne. Analizując zebrane wytwory, podejmuje się próby zdiagnozowania m.in. miejsca, postaw słuchaczy nawiązujących do historii własnego życia szkolnego, ich namysłu nad nauczycielskimi sposobami postrzegania uczniów i celu takich zapisków. Zwraca też uwagę na rolę emocji oraz pamięci indywidualnej przeszłości w tworzeniu wspomnień szkolnych, rozwijaniu rozmaitych nawyków myślenia o uczniu, nauczycielu, literaturze. Traktując owe zapiski także jako diagnozę problemów szkoły i polonistyki szkolnej, pisze o dużym znaczeniu takich refleksji dla ich autorów, odbiorców oraz dla edukacji szkolnej i uniwersyteckiej.

Słowa kluczowe: uczeń/student, nauczyciel, wspomnienia i problemy szkolne, pamięć autobiograficzna, edukacja polonistyczna

\section{"I remember when at school..." On the importance of autobiographical elements not only for their authors - the students of Polish studies}

Summary

The author of the article begins with a discussion of how specialists in the field understand the term "autobiography" and what its role is. Then, she presents the results of an analysis of autobiographical elements present in texts by 136 students starting Polish studies. In analysing the collected works, she diagnoses the places and attitudes of students who referred to stories from their own school lives, their considerations about their teachers' ways of perceiving pupils, and the purpose of such texts. She also indicates the roles of emotions and the recollections of the personal past in 
creating school memories, and developing various ways of thinking about pupils, teachers, and literature. In treating those texts as diagnoses of the problems of school and school Polish education, she discusses the importance of such observations for their authors, readers and for school and university education.

Keywords: pupil/student, teacher, recollections and school problems, autobiographical memory, Polish philological education

Danuta Lazarska, Ph.D., professor at the Chair of Teaching Literature and the Polish Language, Institute of Polish Philology, Pedagogical University of Cracow; proponent of empirical studies; the author of numerous publications on teaching and the methodology of teaching Polish, e.g. the monograph: Uczen $w$ roli publicysty. Przygotowanie piętnastolatków do życia społecznego w kształceniu polonistycznym (2006), Osoba ucznia w świadomości studentów polonistyki. O związku literaturoznawstwa $z$ dydaktyka (2015); the editor and co-editor of editions of Studia ad Didacticam Litterarum Polonarum et Lingue Polonae Pertinentia, (Annales Universitas Pedagogicae Cracoviensis series). 